\title{
Assessment of Drilling Waste Addition on the Salinity of Soils and Growth of Selected Grass Species
}

\author{
Justyna Kujawska ${ }^{1 *}$, Henryk Wasąg ${ }^{1}$, Adam Gawryluk ${ }^{2}$ \\ 1 Lublin University of Technology, Nadbystrzycka 40B, 20-618, Lublin, Poland \\ 2 University of Life Science in Lublin, Akademicka 15, 20-950 Lublin, Poland \\ * Corresponding author's e-mail: j.kujawska@pollub.pl
}

\begin{abstract}
The soils that sustained damage from the mining industry are threatened with high salinity. The aim of the research involved assessing the impact of drilling wastes on the salinity of soils, and the influence of salinity on the germination and growth of various grass species. The research involved the energy, germination capacity and growth of four grass species: tall fescue Festuca arundinacea (cv. Odys), red fescue Festuca rubra (cv. Areta), perennial ryegrass Lolium perenne (cv. Gazon) and smooth meadow grass Poa pratensis (cv. Alicja) in the soils with various amount of drilling wastes addition and different salinity. The drilling waste addition in the amount of $5 \%, 10 \%$, $15 \%, 20 \%, 30 \%(\mathrm{v} / \mathrm{v})(\mathrm{pH} 4.1, \mathrm{EC}=8.84 \mu \mathrm{S} / \mathrm{cm})$ significantly increased the salinity of the prepared mixtures to the levels of $>2.5 \mathrm{dS} / \mathrm{m}$, determined as harmful for most plants. Studies indicated that $5 \%, 10 \%$ and $15 \%(\mathrm{v} / \mathrm{v})$ drill cuttings addition does not inhibit the growth of the considered grasses, while at the $25 \%$ addition of drill cuttings, the length of seedlings and roots is halved in comparison to the control sample without drilling waste addition. The mixture with $30 \%$ drilling waste addition, characterized by the salinity of $18 \mathrm{dS} / \mathrm{m}$, inhibits the growth of all considered plant species. The conducted discrimination analysis indicated that cv. Gazon and cv. Odys differ from the other considered grass species, exhibiting the highest resistance to salinity caused by drilling waste addition. In turn, cv. Alicja was characterized by the lowest tolerance to salinity.
\end{abstract}

Keywords: drill cuttings, reclamation, salinity

\section{INTRODUCTION}

Rapid development of industry threatens the natural environment in numerous ways. Increased occurrence of drillings related to the prospecting of gas or crude oil results in the generation of drilling wastes [Borowski et al. 2019]. The growing amount of drilling wastes contributes to the largest group of industrial wastes, i.a. from coal mining. These wastes cause the appearance of degraded lands, including heaps of tailings or postdrilling areas. Their proper management facilitates reclamation and later use. In 2017, the nonreclaimed areas in Poland amounted to 8376.8 ha, and only 18.2 ha was reclaimed [GUS, 2018].

Another limitation in reclaiming post-industrial areas pertains to the salinity of industrial wastes. Their storage may raise the salinity of soil, when the upper parts of soil profiles with low soil content are mixed with the waste characterized by high salinity. Worldwide, more than 400 Mha are saline. In Poland, the estimated area of saline soils reaches approximately 5420 ha [Wasilewski et al. 2015]

Cultivation of plants on such areas is difficult and sometimes does not yield the expected results. Salinity is connected with excessive amount of dissolved ions in the soil solution, especially $\mathrm{Na}^{+}, \mathrm{Cl}^{-}, \mathrm{SO}_{4}{ }^{2-}, \mathrm{HCO}_{3}^{-}$, and rarely $\mathrm{K}^{+}$, $\mathrm{Ca}^{2+}, \mathrm{Mg}^{2+}, \mathrm{NO}_{3}^{-}$. This leads to the physiological drought, which makes the seeds during the germination phase more vulnerable to the salinity stress [Borowski 2008].

The simplest, but also most time-consuming method of reclamation is to employ the natural plant capacity for the removal of excess soil. 
Such plants should be characterized by resistance to elevated salinity in order to facilitate rapid growth and produce large amount of biomass [Jakubiak et al. 2008].

Studies on the selection of plants capable of growing on the areas degraded by various types of industrial activity and saline soils are constantly being conducted [Kienberg et al., 2014, Giannini et al. 2016].

Grasses are the most abundant type of plants. They are characterized by a large morphological and practical diversification. These plants are found in various habitat conditions. Such properties enable to use grasses not only as animal fodder but also as decorative plants and lawns. The term lawn grasses is very broad, since it encompasses both the intensively maintained and used areas, including, e.g. tennis courts or gold fields, to extremely extensive areas like heaps of brown or hard coal tailings [Przydatek et al. 2006].

Due to the common application of grasses, an attempt was made in this work to evaluate the growth of selected grass types on the soil with the addition of drilling wastes characterized by high salinity. The tolerance of various grass species to salinity was described in the studies by Yuying et al. (1999), Xiaofang et al. (2000), Hujun et al. (2001) and Pawluśkiewicz (2000). For instance, in the research conducted by Stawicka et al. (2006) on the soils characterized by salinity of $0.3-1.2 \mathrm{dS} / \mathrm{m}$, the monocotyledonous species were the most useful. These included Festuca rubra, Lolium perenne, and Poa pratensis [Stawicka et al. 2006]. However, the results of studies conducted on the grasses cultivated on saline soils are often ambiguous. For instance, Hujun et al. (2001) considered Lolium perenne as a highly valuable species that is tolerant to salinity, while Festuca rubra is considered moderately or low tolerant. In turn, Pawluśkiewicz (2000) observed no difference in the germination of Lolium perenne and Festuca rubra on the substrate with the salinity of $8 \mathrm{mS} / \mathrm{cm}$ [Hujum et al. 2001, Pawluśkiewicz B. 2000]. This means that grass seeds are highly differentiated within a species and even a variety, in respect to salinity tolerance, which was also noted by Hanslin and Eggen (2005).

The aim of the work is to assess the impact of drilling wastes on soil salinity as well as the influence of salinity on germination and growth of various grass species.

\section{MATERIALS AND METHODS}

The conducted pot experiment investigated the influence of drilling wastes (cuttings) from shale gas extraction on the germination of grass seeds forming the roadside grassy ecosystems [Stawicka 2003, Harkot i in. 2005].

The drilling wastes, i.e. cuttings, originated from the waste facility in Luchów near Biłgoraj, Poland. The granular composition of the drill cuttings comprised the sand fraction $(2 \div 0.05 \mathrm{~mm})$ that constituted $75 \% \pm 0.57$ of total mass of each investigated sample. The dust fraction $(0.05 \div 0.002 \mathrm{~mm})$ corresponded to $18 \% \pm 0.46$, whereas the loam fraction $(<0.002 \mathrm{~mm})$ constituted only $7 \% \pm 0.33$ of total material mass. The drilling waste is characterized by a highly alkaline $\mathrm{pH}$ (9) and electric conductivity of EC $>40 \mathrm{dS} / \mathrm{m}$.

The following grass species were investigated: Festuca arundinacea (cv. Odys), Festuca rubra (cv. Areta), Lolium perenne (cv. Gazon) and Poa pratensis (cv. Alicja). Sterile sand with the granular composition of loamy sand and the content of sand fraction $>90 \%$ (sterilizied for $60 \mathrm{~min}$ at $180^{\circ} \mathrm{C}$ ) was used as the substrate for cocci growth. The sand was placed in pots (volume 11,81 , upper $24 \mathrm{~cm}$, height $30 \mathrm{~cm}$ ) after polluting it with drilling wastes in 5\%,10\%,15\%,20\% and $30 \%$ ratios of drilling wastes to substrate/sand weight. Unpolluted sand constituted the control object. The mixtures named: P0, P5, P10, P15, P20, P30. A 100 seeds were placed in each pot, after considering the germination capacity of seeds characterizing each of the considered varieties.

The energy and shooting capacity of cocci was determined in Petri glasses $(3 \times 50$ cocci) on 3 plies of cellulose chromatography papers (Whatman No3001917), which was wetted with $3 \mathrm{ml}$ of distilled water on a daily basis. The energy of seed germination ( $\%$ of seeds that germinated after a longer period of time) of $F$. arundinacea and L. perenne was determined after 5 days, F. rubra and $F$. ovina after 7 days, while $P$. pratensis after 10 days. The germination capacity ( $\%$ of seeds that germinated after a longer period of time) of $F$. arundinacea, $L$. perenne were determined after 14 days, F. rubra and F. ovina after 21 days and P. pratensis after 28 days [Dorywalski i wsp., 1964]. During the research, the humidity of substrate in all pots was maintained at a constant level ( $80 \%$ field water capacity). The pots were placed in containers with distilled water, maintaining its constant level $(2 \mathrm{~cm})$. The studies were conducted 
for 6 weeks under 12-hour artificial lighting conditions, provided using SON-T AGRO lamp (approx. 400 Lux). The air temperature in the room reached $24-25^{\circ} \mathrm{C}$.

The growth rate of seedlings was evaluated on the basis of the root length and seedling height (in $\mathrm{mm}$ ), in $5^{\text {th }}, 10^{\text {th }}, 15^{\text {th }}, 20^{\text {th }}, 25^{\text {th }}, 30^{\text {th }}, 35^{\text {th }}, 40^{\text {th }}$, $50^{\text {th }}, 55^{\text {th }}$ and $60^{\text {th }}$ day from the beginning of the experiment. The height of seedlings was measured form the caryopsis base to the tip of the fully developed blade, while the root length from the caryopsis base to the tip of root.

The electrical conductivity of the prepared mixtures was carried out with the conductometric method, in line with PN-EN 27888:1999 standard.

\section{Statistical analysis}

While elaborating the results of studies conducted in repetitions, the arithmetical means and means standard deviations were calculated. In order to assess the significance of differences between the mean values, the statistical analyses conducted, based on the T Tukey's test at the significance level of $\alpha=0.05$. This test enabled to conduct a detailed comparison of mean values by indicating Tukey homogeneous groups, marked with letters. The mean values of particular parameters determined for the compared substrates marked with the same letter indicate that they belong to a statistically homogeneous group, meaning the lack of a statistically significant difference between them.

The impact of investigated parameters on the species of considered grasses was assessed by means of the discriminant analysis.

The calculations were carried out using Microsoft Excel 2010 and Statistica 13.0 software package (licensed for the Faculty of Environmental Engineering of Lublin University of Technology).

\section{RESULTS AND DISCUSSION}

Addition of drilling wastes in all applied doses increases the electrical conductivity (EC) values of sand, which was presented in Table 1. The conducted post hoc statistical analysis using T-test statistical significance indicated that the addition of drilling fluids had a statistically significant influence on the EC values in particular mixtures.
Table 1. Electrical conductivity values of the considered mixtures

\begin{tabular}{|c|c|}
\hline Mixture & EC $[\mathrm{dS} / \mathrm{m}]$ \\
\hline 0 & $0.884^{\mathrm{a}}$ \\
\hline P-5 & $5.03^{\mathrm{b}}$ \\
\hline P-10 & $6.4^{\mathrm{c}}$ \\
\hline P-15 & $9.5^{\mathrm{d}}$ \\
\hline P-20 & $15.3^{\mathrm{e}}$ \\
\hline P-30 & $18^{\mathrm{e}}$ \\
\hline
\end{tabular}

Electrical conductivity expresses the capacity of water to conduct electric current, which changes depending on the number and type of ions in the solution expressed in $\mu \mathrm{S} / \mathrm{m}$. This parameter affects the efficiency of cultivated plants, as well as the soil texture, cation exchange capacity, dehydration conditions, organic matter content, salinity and substrate properties [Patel and Lankawada, 2014].

The EC in the substrate with $5 \%$ drilling waste addition increases more than 20 -fold, with $10 \%$ addition - by 45 -fold, while a $15 \%$ addition results in a 73-fold increase in relation to the control soil. These values are statistically significantly different. In the substrates with the highest $20 \%$ and $30 \%$ drilling waste addition, these values increased more than 80 -fold, but the difference was not statistically significant.

While comparing the EC values measured in the produced substrates with the soil salinity scale presented by Patel and Lankawda, it was observed that the drill cuttings addition increases the soil salinity from $\mathrm{EC}<0.08 \mathrm{dS} / \mathrm{m}$ to $0.19-0.75 \mathrm{dS} / \mathrm{m}$. It changes the soil category from "normal" in the control to "injurious" in most crops of all remaining mixtures, since EC $>2.5 \mathrm{dS} / \mathrm{m}$ [Patel and Lankawda, 2014]. Taking into account the plant requirements in terms of EC values of the substrate, it should be purported that they will limit the plant growth to a varying degree. Therefore, selection of appropriate plant species, e.g. grasses with high tolerance to salinity, is necessary. It will then be possible to use it for reclamation of postdrilling areas.

An increase in EC of soils following the addition of drilling wastes was observed by numerous scholars [Bauder et al., 2005; Kisic et al., 2009; Yao et al., $2014 \mathrm{a}, \mathrm{b}]$. The studies by Baudera et al. (2005), Lesky et al. (1989) indicated that the addition of spent caused such increase in the sodium content and electrolytic conductivity of soils that it inhibited the growth of plants. None of the cited 
papers described the impact of drilling wastes on the growth of grasses.

In order to evaluate the impact of drill cuttings on the behavior of the considered grass species, the energy and capacity of germination were determined. The germination energy is the percentage of seeds that germinated in the shortest time possible. In turn, the germination capacity enables to check whether the seeds germinated under appropriate conditions and in time.

In the first stage, the germination energy and capacity of grass seeds without drilling waste addition were investigated (Table 2). The germination energy of seeds ranged from $52.7 \%$ for $\mathrm{cv}$. Alicja to $90.7 \%$ for cv. Gazon, while the germination capacity varied from $97.3 \%$ to $85.3 \%$. Among the considered varieties, the highest germination energy was observed in the case of $\mathrm{cv}$. Gazon seeds. For cv. Areta and Odys, the germination energy was statistically significantly different from other grass seeds; the values were similar, reaching approximately $75 \%$. The lowest statistically significant germination energy and capacity were observed for cv. Alicja seeds. No statistically significant differences in germination capacity of cv. Gazon, Odys and Areta were found, reaching the values of over $90 \%$.

Table 3 shows the impact of salinity caused by the addition of drilling wastes on the germination energy capacity of the produced mixtures. The seeds of cv. Gazon grass cultivated on P5 and P10 mixtures grew much faster than the seeds of the control sample. In the case of P15 mixtures,

Table 2. Germination energy and capacity of the considered Grass varieties growing on Petri Glasses

\begin{tabular}{|c|c|c|}
\hline Grass variety & $\begin{array}{c}\text { Germination } \\
\text { energy }\end{array}$ & $\begin{array}{c}\text { Germination } \\
\text { capacity }\end{array}$ \\
\hline Odys & $79.3 \mathrm{a}$ & $97.3 \mathrm{a}$ \\
\hline Alicja & $52.7 \mathrm{c}$ & $85.3 \mathrm{~b}$ \\
\hline Areta & $76.7 \mathrm{a}$ & $96.0 \mathrm{a}$ \\
\hline Gazon & $90.7 \mathrm{~b}$ & $96.7 \mathrm{a}$ \\
\hline
\end{tabular}

the seeds of cv. Alicja, Odys and Areta showed approximately half of the germination energy and capacity of the control sample. The seeds of $\mathrm{cv}$. Alicja grass germinated much slower than others considered seeds. The $20 \%$ and $30 \%(\mathrm{v} / \mathrm{v})$ addition of drilling wastes, characterized by salinity of $15.3 \mathrm{dS} / \mathrm{m}$ and $18 \mathrm{dS} / \mathrm{m}$ statistically significantly reduced the germination energy of all considered plant species.

Figures $1-5$ present the length of seedlings and roots of the considered plant varieties cultivated on mixtures with the addition of drilling wastes on the $5^{\text {th }}, 10^{\text {th }}, 15^{\text {th }}, 20^{\text {th }}, 25^{\text {th }}, 30^{\text {th }}, 35^{\text {th }}$. $40^{\text {th }}$ and $45^{\text {th }}$ measurement day.

The analysis of seedling length indicates that the grasses of cv. Odys, Gazon and Areta did not differ statistically significantly from ones in the control samples at the salinity levels ranging from 5.03 to $9.5 \mathrm{dS} / \mathrm{m}$, but only until the $35^{\text {th }}$ measurement day. In the case of cv. Odys, the length of seedlings from the $40^{\text {th }}$ to $60^{\text {th }}$ measurement day was statistically significantly shorter than in the control sample. On the $60^{\text {th }}$ measurement day, the length of cv. Odys shoots cultivated on P5, P10 and P15 mixtures with the salinity of 5.03, 6.4, $9.5 \mathrm{dS} / \mathrm{m}$, respectively, were about 1.2-fold lower than the control sample. The cv. Areta and Gazon grasses exhibited a different behavior. From the $50^{\text {th }}$ measurement day, at the salinity level of 5.03, a stimulation of cv. Areta and Gazon seedlings growth was noted. On the $60^{\text {th }}$ measurement day, the seedling length of the afore-mentioned varieties reached similar values of $14.3 \mathrm{~cm}$, which is 1.2-fold longer than in the control samples.

At the salinity of $15.3 \mathrm{ds} . / \mathrm{m}$ (P20 mixture), the growth of cv. Odys, Areta and Gazon was affected. The seedling length of these grasses were 1.2-1.6-fold lower than the seedlings in the control sample. On the $60^{\text {th }}$ measurement day, the seedlings of cv. Areta and Gazon were about half the height of the control sample. In the case of cv. Gazon, the growth of seedlings was stunted on the $45^{\text {th }}$ day of the experiment.

Table 3. Germination energy and capacity of selected plant varieties growing on drill cuttings

\begin{tabular}{|c|c|c|c|c|c|c|c|c|c|c|c|c|}
\hline \multirow{2}{*}{ Grass variety } & \multicolumn{4}{|c|}{ Germination energy } & \multicolumn{4}{c|}{ Germination capacity } \\
\cline { 2 - 14 } & 0 & P5 & P10 & P15 & P20 & P30 & 0 & P5 & P10 & P15 & P20 & P30 \\
\hline EC [dS/m] & 0.884 & 5.03 & 6.4 & 9.5 & 15.3 & 18 & 0.884 & 5.03 & 6.4 & 9.5 & 15.3 & 18 \\
\hline Odys & $50.0 \mathrm{a}$ & $50.0 \mathrm{a}$ & $42.0 \mathrm{~b}$ & $18.7 \mathrm{c}$ & $1.3 \mathrm{~d}$ & $0 \mathrm{~d}$ & $60.0 \mathrm{a}$ & $58.7 \mathrm{a}$ & $59.3 \mathrm{a}$ & $59.3 \mathrm{a}$ & $42.0 \mathrm{c}$ & $12.7 \mathrm{~d}$ \\
\hline Alicja & $51.3 \mathrm{a}$ & $30.0 \mathrm{~b}$ & $21.3 \mathrm{c}$ & $18.0 \mathrm{~d}$ & $4.0 \mathrm{e}$ & $0 \mathrm{~d}$ & $61.3 \mathrm{a}$ & $43.3 \mathrm{~b}$ & $40.0 \mathrm{~b}$ & $43.3 \mathrm{~b}$ & $26.7 \mathrm{c}$ & $2.0 \mathrm{~d}$ \\
\hline Areta & $66.0 \mathrm{a}$ & $54.0 \mathrm{ab}$ & $48.7 \mathrm{~b}$ & $24.0 \mathrm{c}$ & $8.7 \mathrm{~d}$ & $0 \mathrm{~d}$ & $67.3 \mathrm{a}$ & $64.7 \mathrm{a}$ & $72.7 \mathrm{~b}$ & $63.3 \mathrm{a}$ & $65.3 \mathrm{a}$ & $3.7 \mathrm{c}$ \\
\hline Gazon & $77.3 \mathrm{a}$ & $78.7 \mathrm{a}$ & $74.0 \mathrm{~b}$ & $60.7 \mathrm{c}$ & $36.0 \mathrm{~d}$ & $8.0 \mathrm{e}$ & $80.0 \mathrm{~b}$ & $88.7 \mathrm{a}$ & $88.7 \mathrm{a}$ & $79.3 \mathrm{a}$ & $72.0 \mathrm{a}$ & $23.3 \mathrm{~b}$ \\
\hline
\end{tabular}




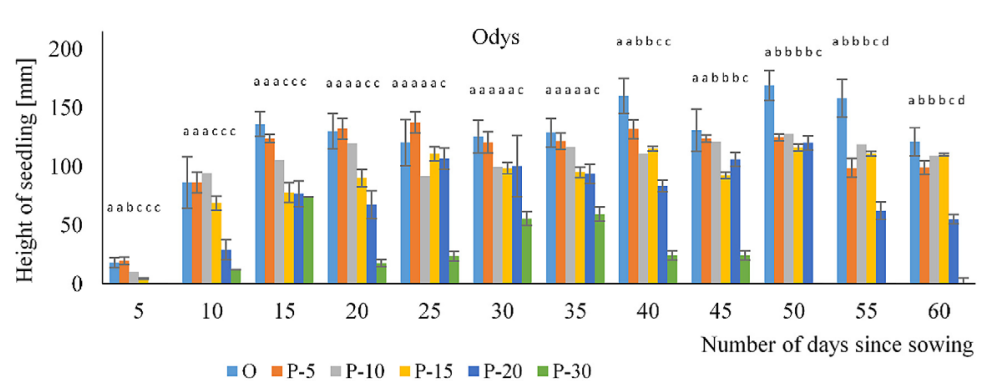

Fig. 1. Seedling height in studied cultivars of the Festuca arundinacea (cultivar Odys) on the $5^{\text {th }}$, $10^{\text {th }}, 15^{\text {th }}, 20^{\text {th }}, 25^{\text {th }}, 30^{\text {th }}, 35^{\text {th }}, 40^{\text {th }}, 45^{\text {th }}, 50^{\text {th }}, 55^{\text {th }}, 60^{\text {th }}$ day after the experiment was established

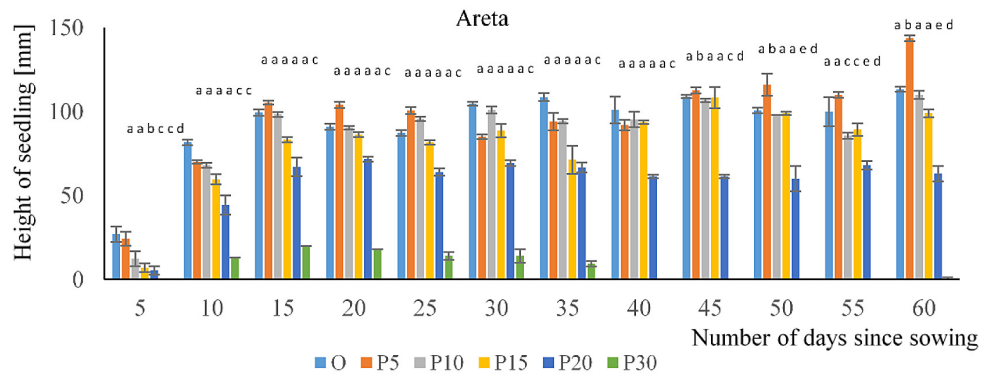

Fig. 2. Seedling height in studied cultivars of the Festuca rubra (cultivar Areta) on the $5^{\text {th }}, 10^{\text {th }}$, $15^{\text {th }}, 20^{\text {th }}, 25^{\text {th }}, 30^{\text {th }}, 35^{\text {th }}, 40^{\text {th }}, 45^{\text {th }}, 50^{\text {th }}, 55^{\text {th }}, 60^{\text {th }}$ day after the experiment was established

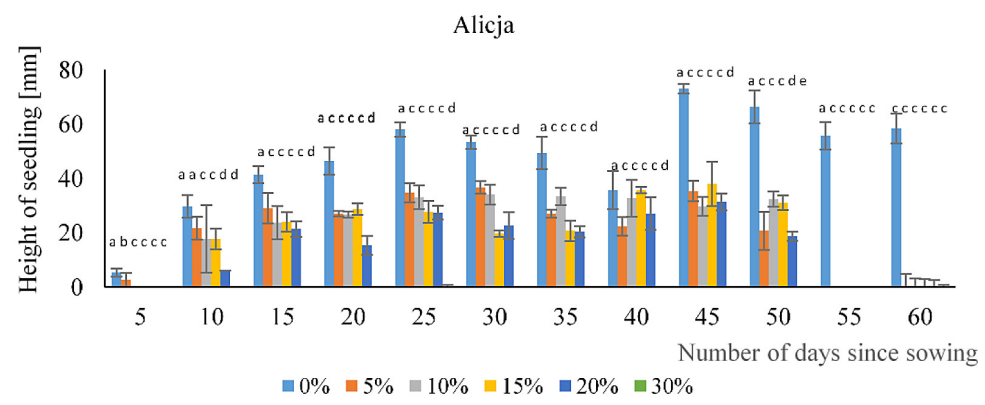

Fig. 3. Seedling height in studied cultivars of the Poa pratensis (cultivar Alicja) on the $5^{\text {th }}, 10^{\text {th }}$, $15^{\text {th }}, 20^{\text {th }}, 25^{\text {th }}, 30^{\text {th }}, 35^{\text {th }}, 40^{\text {th }}, 45^{\text {th }}, 50^{\text {th }}, 55^{\text {th }}, 60^{\text {th }}$ day after the experiment was established

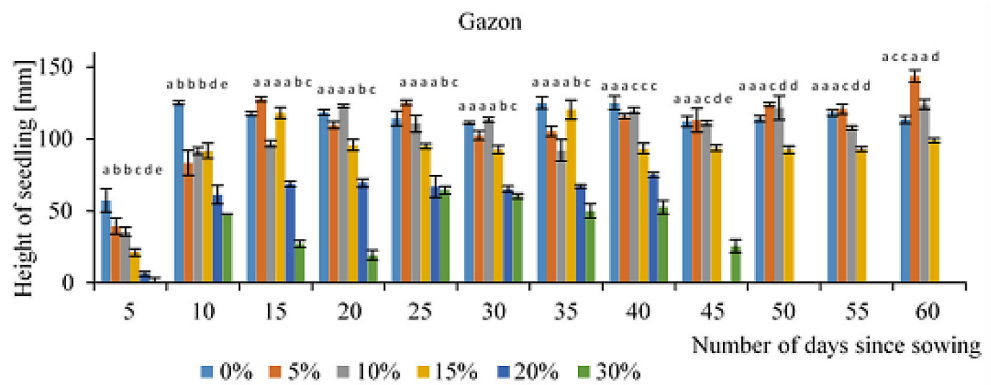

Fig. 4. Seedling height in studied cultivars of the Lolium perenne (cultivar Gazon) on the $5^{\text {th }}, 10^{\text {th }}$, $15^{\text {th }}, 20^{\text {th }}, 25^{\text {th }}, 30^{\text {th }}, 35^{\text {th }}, 40^{\text {th }}, 45^{\text {th }}, 50^{\text {th }}, 55^{\text {th }}, 60^{\text {th }}$ day after the experiment was established

The cv. Alicja grass was the least susceptible to the drilling wastes addition. As it was mentioned before, cv. Alicja was characterized by the lowest germination energy and capacity. The length of cv. Alicja seedlings from the $15^{\text {th }}$ to $50^{\text {th }}$ measurement day cultivated on P5, P10, P15 and P20 mixtures reached the half the height of the control seedlings. These values were statistically significantly lower than the ones in the control. On the $55^{\text {th }}$ day, the growth 


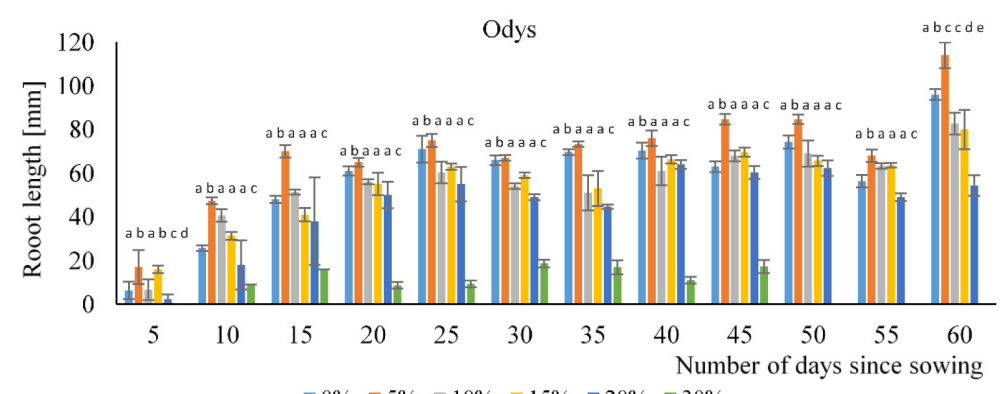

Fig. 5. The length of the main root in studied cultivars of the Festuca arundinacea (cultivar Odys) on the $5^{\text {th }}, 10^{\text {th }}, 15^{\text {th }}, 20^{\text {th }}, 25^{\text {th }}, 30^{\text {th }}, 35^{\text {th }}, 40^{\text {th }}, 45^{\text {th }}, 50^{\text {th }}, 55^{\text {th }}, 60^{\text {th }}$ day after the experiment was established

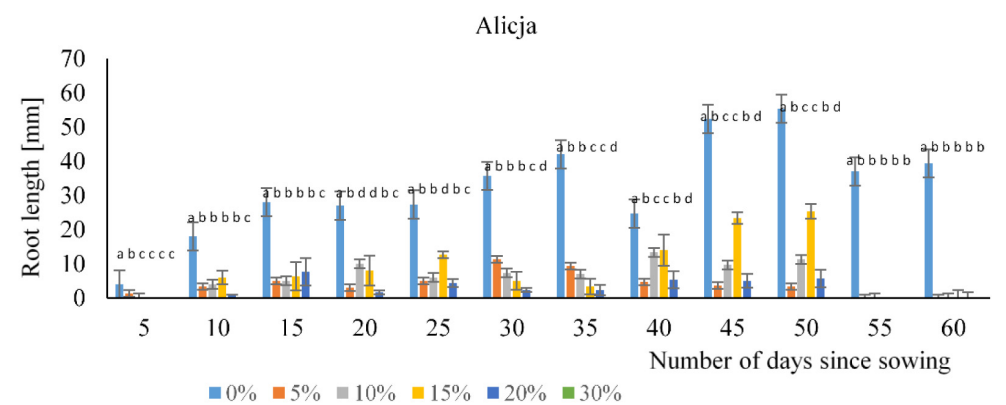

Fig. 6. The length of the main root in studied cultivars of the Poa pratensis (cultivar Alicja) on the $5^{\text {th }}$, $10^{\text {th }}, 15^{\text {th }}, 20^{\text {th }}, 25^{\text {th }}, 30^{\text {th }}, 35^{\text {th }}, 40^{\text {th }}, 45^{\text {th }}, 50^{\text {th }}, 55^{\text {th }}, 60^{\text {th }}$ day after the experiment was established

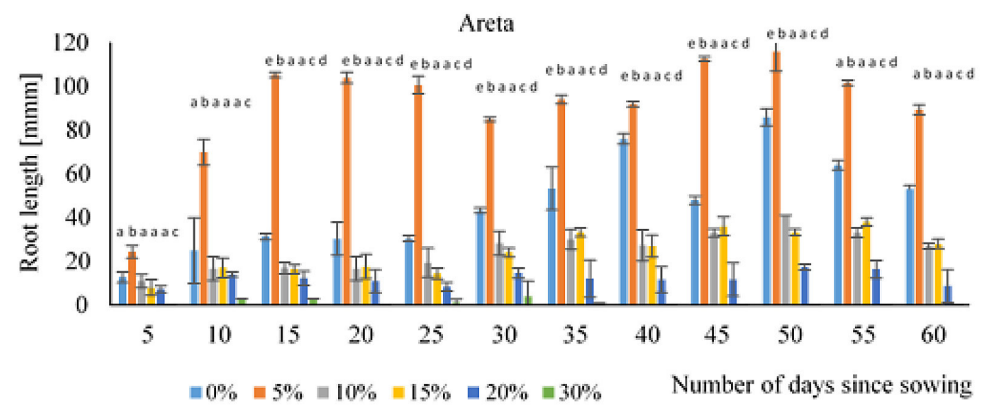

Fig. 7. The length of the main root in studied cultivars of the Festuca rubra (cultivar Areta) on the $5^{\text {th }}$, $10^{\text {th }}, 15^{\text {th }}, 20^{\text {th }}, 25^{\text {th }}, 30^{\text {th }}, 35^{\text {th }}, 40^{\text {th }}, 45^{\text {th }}, 50^{\text {th }}, 55^{\text {th }}, 60^{\text {th }}$ day after the experiment was established

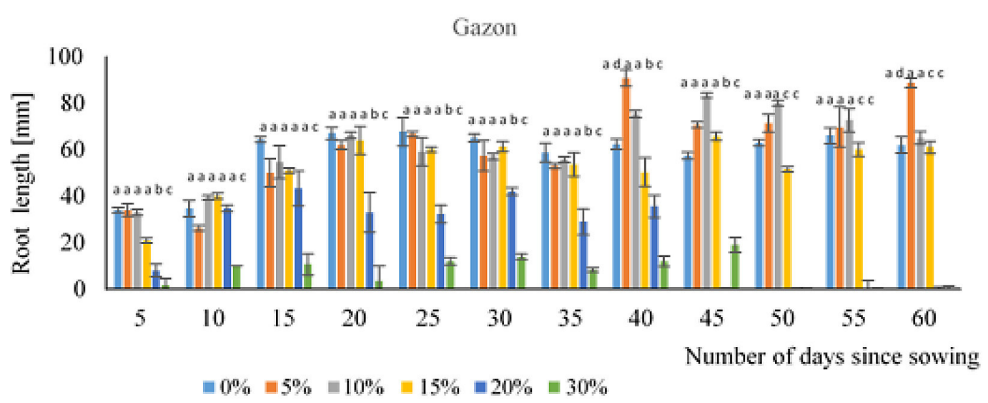

Fig. 8. The length of the main root in studied cultivars of the Lolium perenne (cultivar Gazon) on the $5^{\text {th }}, 10^{\text {th }}, 15^{\text {th }}, 20^{\text {th }}, 25^{\text {th }}, 30^{\text {th }}, 35^{\text {th }}, 40^{\text {th }}, 45^{\text {th }}, 50^{\text {th }}, 55^{\text {th }}, 60^{\text {th }}$ day after the experiment was established

of cv. Alicja grass was completely stunted in all samples.

Salinity of $18 \mathrm{dS} / \mathrm{m}$ (P30 mixture) inhibited the growth of all considered grass varieties to the greatest degree. The seedling growth inhibition has occurred since the beginning of the experiment. On the $15^{\text {th }}$ and $20^{\text {th }}$ measurement day, the $\mathrm{cv}$. Odys seedlings were half the length of the 
ones in the control sample, on the $30^{\text {th }}$ and $35^{\text {th }}$ measurement day, a 2.5 -fold reduction was noted, while on the $40^{\text {th }}$ and $45^{\text {th }}$ day - a 5-fold drop was noted. On the 50th measurement day, the growth of $\mathrm{cv}$. Odys grass was stunted. In the case of $\mathrm{cv}$. Areta, the seedling length was 5-fold shorter than the control sample already on the $15^{\text {th }}$ measurement day, while on the $35^{\text {th }}$ day, the difference was 12 -fold. The growth of cv. Areta seedlings was stunted on the $40^{\text {th }}$ measurement day. In turn, the seedlings of $\mathrm{cv}$. Gazon on $25^{\text {th }}$ to $40^{\text {th }}$ measurement day reached half the length of the seedlings in the control sample. Their growth was stunted on the $50^{\text {th }}$ day. At the salinity level of $18 \mathrm{dS} / \mathrm{m}$, cv. Alicja did not germinate.

The length of cv. Odys and Areta grass shoots cultivated on P5 mixture with the salinity of $5.03 \mathrm{dS} / \mathrm{m}$ was statistically significantly greater than in the control samples and other considered mixtures. In the case of $\mathrm{cv}$. Gazon grown on P5 mixture, the length of shoots exceeded the ones in control samples only from $40^{\text {th }}$ day onward.

While analyzing the influence of P10 and P15 mixtures, exhibiting salinity of $6.4 \mathrm{dS} / \mathrm{m}$ and 9.5 $\mathrm{dS} / \mathrm{m}$ on the length of $\mathrm{cv}$. Odys and Gazon seedlings, they did not differ statistically significantly from the control samples throughout the experiment. In turn, the length of cv. Areta seedlings cultivated on these mixtures were about 2-fold greater than the control sample.

Salinity of $15.3 \mathrm{dS} / \mathrm{m}$ in P20 mixture contributed to the stunted growth of seedlings, especially in cv. Areta and Gazon. Throughout the experiment, the growth of cv. Areta grass roots cultivated on P20 mixture was inhibited. In the case of $\mathrm{cv}$. Gazon seedlings on the $25^{\text {th }}$ measurement day they were half the length of the control sample. Already on the $45^{\text {th }}$ day, the growth of cv. Gazon roots, cultivated on P20 mixture, was completely stunted. In turn, cv. Odys had the root length similar to the control, which was confirmed by a statistical analysis. However, on the $60^{\text {th }}$ measurement day, the length of cv. Odys roots were 1.7fold shorter than in the case of the control.

While analyzing the length of $\mathrm{cv}$. Alicja shoots, the greatest root growth inhibition can be observed at the lowest dose of wastes. The addition of drilling wastes to mixtures inhibited the growth of $\mathrm{cv}$. Alicja shoots, similarly to seedlings. On the 30th measurement day, the length of grass shoots cultivated on P5. P10, and P15 were approximately 5 -fold shorter than in the control (which was confirmed by the statistical analysis.
In turn, the length of shoots on P20 mixture were 17 -fold shorter than in the control. On the $50^{\text {th }}$ measurement day, the growth of shoots was inhibited in all considered mixtures.

Salinity at the level of $18 \mathrm{dS} / \mathrm{m}$ (P30 mixture) inhibited the growth of roots in all considered grass varieties. The growth of cv. Alicja was inhibited throughout the entire measurement period; in the case, of cv. Areta, it was stunted on the $40^{\text {th }}$ day, while cv. Odys and Gazon - on the $50^{\text {th }}$ day.

Our research correlates with other studies which indicated that salinity has a negative impact on the growth of plants, the length of seedlings and roots decreases linearly with salinity increase.

The grass tolerance to salinity can be presented in the following order: tall fescue $=$ Festuca arundinacea (cv. Odys) $>$ perennial ryegrass $=$ Lolium perenne $(\mathrm{cv}$. Gazon) $>$ red fescue $=$ Festuca rubra (cv. Areta)> smooth meadow grass Poa pratensis (cv. Alicja).

Borowski indicated that perenne, Festuca rubra, Agrostis capillaris, Poa pratensis tolerate the salinity in the range from $5 \mathrm{dS} / \mathrm{m}$ to $10 \mathrm{dS} / \mathrm{m}$ [Borowski, 2008].

In our studies, the growth of $\mathrm{cv}$. Alicja roots (Poa pratensis) was inhibited already at the salinity of $5 \mathrm{dS} / \mathrm{m}$. On the $15^{\text {th }}$ measurement day, the length of $\mathrm{cv}$. Alicja roots was 5 -fold shorter than in the control sample.

Literature suggests that the seedlings of L. perenne exhibit varied tolerance to the salinity stress [Hujun et al., 2001; Borowski, 2008 a; b; Kusvuran et al., 2015], while P. pratensis should be considered as moderately vulnerable [Friell et al., 2013]. The Lolium perenne seeds showed the highest tolerance to salinity, followed by (in descending order) Festuca rubra, Agrostis capillaris and Poa pratensis. To some extent, our studies confirmed these relationships. However, it is difficult to confirm them unequivocally, as the varieties of investigated grasses. As indicated in the studies conducted by Borowska-Jarmułowiec, the seedling length of Lolium perenne cv. Biilla at the salinity of $100 \mathrm{dS} / \mathrm{m}$ was 1.3 -fold shorter than in the control sample, whereas the growth of cv. Sojka was completely stunted [Pawluśkiewicz 2000, Xiaofang et al. 2000, Hujun 2001, Yongqin et al. 2003, Stawicka et al. 2006].

Discriminant analysis was carried out to determine which of the considered parameters stand out among the investigated grass species. The tables 4 and 5 presented the results of the conducted discriminant analysis. 
Table 4. Mean canonical variables

\begin{tabular}{|c|c|c|}
\hline \multirow{2}{*}{ Grass variety } & \multicolumn{2}{|c|}{ Mean canonical variables } \\
\cline { 2 - 3 } & $\begin{array}{c}\text { First discriminant } \\
\text { function }\end{array}$ & $\begin{array}{c}\text { Second } \\
\text { discriminant } \\
\text { function }\end{array}$ \\
\hline Odys & 0.87429 & 0.116193 \\
\hline Gazon & 0.78099 & 0.182006 \\
\hline Alicja & -1.50503 & 0.212974 \\
\hline Areta & -1.5025 & -0.511173 \\
\hline
\end{tabular}

The first discriminant function sets cv. Odys apart from the other varieties, while in the second discriminant function - cv. Gazon is set apart. The values of coefficients of discrimination indicate that salinity has the greatest influence on the first discriminant function, i.e. cv. Odys grass. The length of shoots and roots also influences this function in a statistically significant way.

\section{CONCLUSIONS}

1. The Festuca arundinacea (cv. Odys), Lolium perenne (cv. Gazon) and Festuca rubra (cv. Areta) grasses tolerate the salinity caused by drilling waste addition up to $6 \mathrm{dS} / \mathrm{m}$.

2. In the conducted studies, certain differences in shoot length can be noted depending on the dose of wastes and the type of grass variety. The obtained tolerance of grasses to salinity is as follows (descending order): Festuca arundinacea $(\mathrm{cv}$. Odys $)>$ perennial ryegrass $=$ Lolium perenne $(\mathrm{cv}$. Gazon $)>$ red fescue $=$ Festuca rubra (cv. Areta) $>$ smooth meadow grass $P$ Poa pratensis (cv. Alicja).

3. The statistical analysis - discriminant analysis indicates Festuca arundinacea (cv. Odys) among the considered grass varieties.

4. The results of studies indicate that Festuca arundinacea (cv. Odys) and Lolium perenne (cv. Gazon) can be applied for the reclamation of post-drilling areas; however, constant monitoring of the impact of wastes on the soil properties is required.

\section{REFERENCES}

1. Bauder T.A., Barbarick K.A., Ippolito J.A., Shanahan J.F., Ayers P.D. 2005. Soil properties affecting wheat yields following drilling-fluid application. Journal of Environmental Quality, 34, 1687-1696.
Table 5. Discriminant function coefficients

\begin{tabular}{|l|c|c|}
\hline \multirow{2}{*}{ Group } & \multicolumn{2}{|c|}{$\begin{array}{c}\text { Standardized coefficients of canonical } \\
\text { variables }\end{array}$} \\
\cline { 2 - 3 } & $\begin{array}{c}\text { First discriminant } \\
\text { function }\end{array}$ & $\begin{array}{c}\text { Second } \\
\text { discriminant } \\
\text { function }\end{array}$ \\
\hline Salinity & 0.09001 & -0.001723 \\
\hline Seedling length & 0.02030 & -0.033782 \\
\hline Shoot length & 0.02773 & 0.058288 \\
\hline Measurment time & -0.02553 & -0.009203 \\
\hline
\end{tabular}

2. Borawska-Jarmułowicz B., Mastalerczuk G., Gozdowski D., Małuszyńska E., Szydłowska A. 2017. The sensitivity of Lolium perenne and Poa pratensis to salinity and drought during the seed germination and under different photoperiod conditions. Zemdirbyste-Agriculture, 104(1), 71-78.

3. Borowski E., 2008. Studies on the sensitivity of some species and cultivars of lawn grasses on salinity with sodium chloride during the seed germination and first year of growth. Folia Horticulturae, 20 (1), 81-98.

4. Borowski G., Kujawska J., Wasąg H. 2019. The effect of zeolite for heavy metals removal from drilling mud wastewater. Physicochemical Problems of Mineral Processing. vol. 55(6), 1467-1474.

5. Dorywalski J., Wojciechowicz M., Bartz J. 1984. Metodyka oceny nasion. Państwowe Wydawnictwo Rolnicze i Leśne, Warszawa

6. Friell J., Watkins E., Horgan B. 2013. Salt tolerance of 74 turfgrass cultivars in nutrient solution culture. Crop Science, 53, 1743-1749.

7. Giannini T.C., Giulietti A.M., Harley R.M., Viana P.L., Jaffe R., Alves R., Pinto C.E., Mota N.F.O., Caldeira Jr C.F., Imperatriz-Fonseca V.L., Furtini A.E., Siqueira J.O., 2016. Selecting plant species for practical restoration of degraded lands using a multiple-trait approach. Austral Ecology, 42(5), 510-521.

8. Hanslin H.M., Eggen T., 2005. Salinity tolerance during germination of seashore halophytes and salt-tolerant grass cultivars. Seed Sci. Res., 15(1), 43-50.

9. Harkot W., Wyłupek T., Czarnecki Z. 2005. Grasses on the selected roadsides of Lublin region. Grassland Science in Poland, 8, 71-79.

10. Hujun L., Youzhen G., Jihe W., Mingui H., Zihui Y. 2001. A comparison on salt tolerance of 28 breeds of cold type lawn grass. Acta Pratacult. Sinica. 10(3), 52-59.

11. Kienberg O., Thill L., Baumbach H.. Becker T. 2014. Amethod for selecting plant species for reintroductionpurposes: a case study on steppe grassland plants inThuringia (Germany). Tuexenia, 34, 467-88. 
12. Kisic I., Mesic S., Basic F., Brkic V., Mesic M., Duran G., Zgorelec Z., Bertovic L. 2009. The effect of drilling fluids and crude oil on some chemical characteristics of soil and crops. Geoderma, 149, 209-216.

13. Kusvuran A., Nazli R. I., Kusvuran S. 2015. The effects of salinity on seed germination in perennial ryegrass (Lolium perenne L.) varieties. Turkish Journal of Agricultural and Natural Sciences, 2 (1), 78-84.

14. Lesky M.J., Staniland R.P., Warren R.J., 1989, Effects of spent fresh-water gel chem drilling mud on cultivated land near Lloydminster, F.R. Engelhardt (ed.), Drilling Wastes, Elsevier Applied Science Publishers Ltd, Barking, Essex, 395-411.

15. Patel D., Lankawda M.M. 2014. Study of soil's nature by $\mathrm{pH}$ and soluble salts through EC of KalolGodhra taluka territor. Pelagia Research Library Der Chemica Sinica, 5(2), 1-7.

16. Pawluskiewicz B. 2000. Germination and initial development of turfgrasses in conditions of bed salinization and alkalization. Łąkarstwo w Polsce, 3, 119-128.

17. Przydatek T., Jurkowski M., Gawęcki J., Gierula A. 2006. Importance of grass species and varieties for turfing reclamation of areas of varied utility. Zeszyty Naukowe Uniwersytetu Przyrodniczego we
Wrocławiu Rolnictwo LXXXVIII, 545, 249-253.

18. Report Poland Statistical Office. Enviromental 2018. https://stat.gov.pl/en/topics/environmentenergy/environment/environment-2018,1,10.html

19. Stawicka J. 2003. Grasses and leguminous plants on urban street lawns (an example of Warsaw and Plock). Biuletyn Instytutu Hodowli i Aklimatyzacji Roślin, 225, 277-288.

20. Stawicka J., Wysocki C., Wieczorek J. 2006. The influence of soil salinity on floral variability of street lawns in Warsaw. Annals of Warsaw Agricultural University SGGW Horticulture (Landscape Architecture), 27, 73-81.

21. Wasilewski M., Brzóstowicz A., Matuszak-Slamani R. 2015. Evaluation of sodium chloride effect on growth and photosynthesis of selected Barley Cultivars. Acta Agrophysica, 22(2), 209-218.

22. Yao L., Naetha M.A. 2014a. Soil plant response to unused potassium silicate drilling fluid application. Ecological Engineering, 73, 461-468.

23. Yao L., Naetha M.A. 2014b. Spent potassium silicate drilling fluid affects soil and leachate properties. Water Air Soil Pollution, 225, 2156-2171.

24. Du Y., Chen X., Shen W., Wan P., 2003. A screening of the salt tolerance variety of lawn grass by biotechnology. Acta Agriculturae Shanghai, 19(1), 37-40. 